\title{
CELEBRATING A DECADE OF PROGRESS AND PREPARING FOR THE FUTURE: OCEAN INFORMATION FOR RESEARCH AND APPLICATION
}

\author{
Antonio J. Busalacchi \\ Earth System Science Interdisciplinary Center (ESSIC), 5825 University Research Court, Suite 4001 \\ University of Maryland, College Park, MD 20740-2823, USA \\ Email: tonyb@essic.umd.edu
}

\begin{abstract}
This paper provides a retrospective of how the ocean observation system has evolved since OceanObs'99. It also provides research and application examples indicating how the next decade of development for ocean observations will evolve to become an integral component of climate services. The paper begins with the original motivation and reasons for organizing the OceanObs'99 Conference, and with this as a basis, conveys the vision for the OceanObs' 09 Conference by focusing on five principal areas: a global perspective, seasonal to decadal climate prediction, forecasting of marine variability, sustainable management, and longerterm trends. Key examples where successes were made by the GOOS (Global Climate Observing System) community since 1999 are highlighted especially in the development of physical oceanography capabilities. Additionally, the paper introduces challenges that still remain in each area, inclusive of examples of how the GOOS will be critical in answering questions or providing input to marine core services and linkages to climate services.
\end{abstract}

\section{INTRODUCTION}

Increasingly, the major global environmental change programs are being asked to demonstrate the societal relevance of the research they sponsor and support. For example, the World Climate Research Programme (WCRP) supports climate related decision-making and planning for adaptation to climate change by developing the science required to improve climate predictions and our understanding of human influence on climate. Since 2005 there has been a new overlay to the mission and objectives of the WCRP relating to its new strategic framework, i.e., for use in an increasing range of practical applications of direct relevance, benefit, and value to society. In this regard the oceans play a major role in the research agenda for the WCRP and ocean research has been one of the fundamental underpinnings of the WCRP as evidenced by the WCRP being one of the original "parents" and sponsors of OceanObs'99.

The overall purpose of OceanObs'09 as stated in the conference objective statement was to strengthen and enhance the international framework under the Global Climate Observing System, (GCOS), the Global Ocean
Observing System (GOOS), the World Climate Research Programme (WCRP), the International GeosphereBiosphere Programme (IGBP) and supporting regional and national frameworks for sustained world ocean observing and information systems supporting the needs of society regarding ocean weather, climate, ecosystems, carbon, and chemistry. However, the byline of the conference truly summarizes the future direction for the decade ahead "Ocean information for society: sustaining the benefits, realizing the potential"; for it is this tagline which really points to the direction and the challenges that confront us for the decade ahead.

A conference such as OceanObs'09 provides an opportunity to look back at the progress and accomplishments of our community over the past decade. Ten years ago in St. Raphael, France, the objective of OceanObs'99 was to review scientific climate program priorities and existing and planned operational efforts that address the priorities of GOOS and GCOS. Specifically to:

i) build consensus on the blend of methods and their uses and value;

ii) build an appreciation for how each component contributes and how the system considered as a single entity works;

iii) document the techniques, the investment in particular elements, and the way data are used for research and routine applications;

and probably the most important,

iv) build the foundations for a new era in oceanography, one where research and operational systems are mutually supportive and beneficial, and one where the rapid and wide distribution of information (data, methods and products) is accepted as preferred modus operandi.

Taken together OceanObs'99 laid out a new paradigm for oceanography.

Just three weeks prior to OceanObs'09, approximately 150 of the world's nations came together in Geneva, Switzerland for the Third World Climate Conference 
(WCC-3) titled "Better climate information for a better future" with the overall purpose of discussing and designing a global framework for climate services. In certain areas and approaches going back to the foundation put forth by OceanObs'99, the oceanographic community has a 10 year head start in the provision of such services. As outlined in the conference statement, the WCC-3 called for a major strengthening of the essential elements of a global framework for climate services, namely:

i) The Global Climate Observing System and all its components and associated activities; and the provision of free and unrestricted exchange and access to climate data;

ii) The World Climate Research Programme, underpinned by adequate computing resources and increased interaction with other global climate relevant research initiatives

iii) Climate services information systems taking advantage of enhanced existing national and international climate service arrangements in the delivery of products including sector oriented information to support adaptation activities

iv) Climate user interface mechanisms focused on building linkages and integrating information, at all levels, between the providers and users of climate services; and

v) Efficient and enduring capacity building through education, training, and strengthened outreach and communication.

Many of these same issues were confronted head-on at OceanObs'09.

If one were to revisit the vision statement going into OceanObs'09 one would note the stated importance of routine and sustained provision of global information regarding the marine environment sufficient to meet society's decision-making needs for useful forecasts of marine variability (including physical, biogeochemical, ecosystems, and living marine resources), of seasonal to decadal climate variability, sustainable management of living resources, and for assessment of longer-term trends. For the purposes and organization of this paper such a vision can be condensed into five main headings:

- Global perspective,

- Seasonal to decadal climate prediction,

- Forecasting of marine variability,

- Sustainable management, and

- Longer-term trends.

\section{GLOBAL PERSPECTIVE}

Today's global ocean perspective afforded by in situ and spaced-based ocean observations has its roots in the WCRP Tropical Ocean Global Atmosphere (TOGA) and World Ocean Circulation Experiment (WOCE) programs of the 1980's and 1990's. At the time of OceanObs'99, and four years after conclusion of the TOGA (Tropical Ocean-Global Atmosphere) program, the TAO (Tropical Ocean-Atmosphere) array remained in force measuring ocean-atmosphere coupling in the tropical Pacific Ocean, and the beginning of the backbone of the PIRATA (Prediction and Research Moored Array in the Atlantic) array in the tropical Atlantic had just begun. Today, 10 years later, the TAO array has expanded to be the TAOTRITON (Triangle Trans-Ocean Buoy Network) array in the Pacific with a series of standard moorings, flux reference sites, $\mathrm{CO}_{2}$, and biochemistry sites, an expanded PIRATA array in the tropical Atlantic, and the beginnings of a RAMA (Research Moored Array for African-Asian-Australian Monsoon Analysis and Prediction) array in the tropical Indian Ocean [1] Although the TOGA program was originally designed to encompass ocean-atmosphere coupling in all three tropical oceans (but in reality only focused on the Pacific), years later we now see that being realized emerging up and out of the tropical Pacific, expanding to the tropical Atlantic, and most recently to the Indian Ocean. Access to such observations of sea surface temperature, upper ocean heat content, and surface vector winds has permitted real-time monitoring of air-sea interaction key to the development of seasonal climate forecasting methodologies [2].

A major legacy of the WOCE program was the development of profiling float technology and the attainment of the Argo (Global array of free-drifting profiling floats) program goal of deploying more than 3000 profiling floats across the global ocean. Although most of the global ocean is adequately covered by Argo (Array for Real-Time Geostrophic Oceanography) there are still problem areas that need continued and specific attention, especially the high latitude oceans [3]. With Argo in mind the future global XBT (Expendable Bathythermograph) network was redesigned at OceanObs'99 to consist of frequently repeated and high density XBT lines to be transmitted in both real-time and delayed mode. With few exceptions most of the XBT network redesigned in 1999 has been realized [4]. Similarly, the Global Sea Level Observing System (GLOSS) sea level network has emphasized, over the past 10 years, the importance of near real-time and fast delivery sea level stations. These upgraded stations provide high frequency sea level observations necessary for understanding sea level variability in addition to secular sea level rise. Near real-time stations provide data typically within one hour of collection and fast delivery 
stations within one month of the observation [5]. A new ocean observing element that has emerged since St. Raphael has been the OceanSITES (OCEAN Sustained Interdisciplinary Time series Environment observation System) program. Consisting of approximately 100 moorings, these fiducial or sentinel sites provide high quality air-sea flux data in key, unique, or strategic portions of the global ocean transmitting their observations in either real-time or delayed mode [6].

Taken as a whole, the various oceanographic platforms provide a rich and complementary series of observations that yield a global perspective for the world ocean. At present, on any given day, there may be more than 4000 different oceanographic platforms reporting in real-time. Since OceanObs'99 there has been a dramatic rise in the number of platforms and the number of oceanographic observations recorded each year. Whereas in 1999 there were approximately 4.5 million oceanographic reports, today there are more than 16 million oceanographic reports taken each year from ships, moored buoys, drifting buoys ships, and coastal stations [7 and 8] Access to these physical oceanographic data with increasingly comprehensive coverage have permitted refinement of atlases of global surface heat fluxes [9 and 10]. Similarly, the WOCE-JGOFS (Joint World Ocean Circulation Experiment-Global Ocean Flux Study) and the CLIVAR-IOCCP (Climate Variability and Predictability Project-International Ocean Carbon Coordination Project) efforts have led to shipboard observations of surface carbon parameters as well as time series stations of ocean biogeochemistry [11]. These, in turn, have enabled refined estimates of climatological mean annual sea-air $\mathrm{CO}_{2}$ fluxes [12 and 10].

Another major advance in the past 10 years has been the development of ocean data assimilation for both state estimation and ocean/climate forecast initialization [13]. At least 10 different ocean analysis/synthesis products are now being produced relying on different assimilation methodologies ranging from optimal interpolation, 3-D variational techniques to 4-D Var, based on several different core ocean general circulation models. Access to nearly two decades of satellite altimetry data (another legacy from WOCE) together with the rapid expansion of in situ data coverage have served to spur the development of these efforts. Such ocean analyses are produced in either research mode or in support of operational seasonal climate forecasts at major national or international weather prediction centers [14]. Much like atmospheric re-analyses, access to these ocean analyses has permitted ocean diagnostic studies such as the differentiation between thermosteric and halosteric contributions to observed regional sea surface height trends. These ocean products have also enabled ocean heat content and ocean heat transport to be analyzed basin by basin and model by model on decadal time scales.

Although OceanObs'99 was primarily focused on physical oceanographic observations in support of climate science, access to Argo floats has served as a platform of opportunity for other oceanographic disciplines. For example, the standard SeaBird CTD (conductivity, temperature, depth) sensor on Argo floats has been modified to accommodate a dissolved $\mathrm{O}_{2}$ sensor [15]. Approximately 160 floats now report oxygen data as a result of these modified Argo floats. Profiles of dissolved oxygen can now be monitored autonomously and analyzed in conjunction with contemporaneous density observations to study, for example, how oxygen and density become vertically homogenous in regions of convective overturning in mid to high latitudes. The development of the prototype Carbon Explorer floats has permitted the observation of particulate organic carbon and particle flux relative to the development of phytoplankton blooms and associated changes in export production [16]. Even more novel is the use of animal profiles in which, for example, an elephant seal is equipped with a CTD- Fluorescence sensor to obtain temperature, salinity and chlorophyll information in remote or ice covered regions not attainable via more conventional means [17].

In addition to the increase in the number and variety of in situ oceanographic observations over the past 10 years, great strides have also taken place with remotely-sensed observations of the global ocean. Whereas altimetry and scatterometry were relatively mature at the time of OceanObs'99 and continue to be major components of the ocean observation strategy, satellite observations of the global marine biosphere have made considerable progress since then. The launch of several different ocean color sensors such as SeaWiFS (Sea-viewing Wide Fieldof-view Sensor), MODIS (Moderate Resolution Imaging Spectroradiometer) and MERIS (Medium Resolution Imaging Spectrometer) has permitted the production of merged products and better quantified error statistics of chlorophyll concentration at the pixel level from product to product. One of the more impressive new observation technologies has been the Gravity Recovery and Climate Experiment (GRACE) which has provided new insights and reduced uncertainties in measures of ice sheet mass balance, ocean bottom pressure, and mean dynamic topography [18]. Provision of GRACE gravity fields plus satellite altimetry has led to refined estimates of mean dynamic topography that can be compared to the drifterbased techniques such as [19]. New sensors on the horizon include the first ever global retrievals of sea surface salinity provided by the launch of SMOS in 2009 and Aquarius in 2011 [20]. 
It is this global perspective of ocean observations that has been put in place over the past decade that has permitted progress in the areas that follow. This perspective also provides an opportunity and infrastructure to build upon looking to the future.

\section{SEASONAL TO DECADAL CLIMATE PREDICTION}

Coming out of the TOGA decade, ocean observations sustained since TOGA were used to initialize coupled ocean-atmosphere prediction models. The success of these efforts subsequently led to operational seasonal forecast systems at many of the world's major numerical weather prediction centers. The most illustrative example of which was the prediction of the onset and decay of the major 1997-98 El Niño event that occurred just prior to OceanObs'99. Since then application models have been developed to take advantage of this nascent climate prediction skill in areas such as water resources, crop forecasts, and disease vectors [21], hence providing the basis for the concept of climate services.

Beyond the seasonal to interannual time scale, arguably the newest emerging research area of climate prediction over the past 10 years has been on the decadal time scale. Access to more than 15 years worth of altimetric sea level observations have revealed regional variability in sea level rise on decadal time scales [22]. Comprehensive space-time coverage of sea surface height variability has indicated wind-forced Rossby wave signatures that fluctuate on decadal time scales controlled upstream by wind stress curl variability associated with the Pacific Decadal Oscillation [23]. Within the Atlantic, several model studies are beginning to show the ability to hindcast observed indices of SST that serve as proxies for the Meridional Overturning Circulation (MOC) [24, 25 , and 26]. Related modeling studies of the strength of the Atlantic MOC suggest the possibility of predictive skill on decadal time scales as a function of the memory contained within the ocean initial conditions. Access to Argo float information between 1000-2000m should prove increasingly important in future predictability studies of decadal climate variability [27]. As decadal climate prediction is one of the major "grand challenges" for climate services in general and specifically within the WCRP, greater definition of the scope and extent of ocean observations to initialize decadal predictions is needed.

\section{FORECASTING OF MARINE VARIABILITY}

Similar to the discussion and call for global climate services there is a clear need for the sustained provision of ocean information and marine services derived from forecasting of marine variability. In this regard GOOS has played an important role in conceptually designing an end-to-end user driven system of systems [28] to efficiently link ocean observations across a variety of measurement platforms (e.g., remote-sensing, fixed platforms, ships, drifters, autonomous underwater vehicles, and marine mammals) with data management protocols (e.g., metadata standards, access, and archival) with modeling tools (tailored, for example, to current and wave fields, coastal inundation, water quality, population and ecosystem dynamics), and ending with decision support tools for societal goals (e.g., maritime services, weather and climate, natural hazards, public health, ecosystem health, living marine resource). Illustrative of such an architecture are the functional components of the Global Ocean Data Assimilation Experiment (GODAE). The components of GODAE serve to link the GODAE data servers with GODAE assimilation centers with GODAE product servers to support an array of application centers, Numerical Weather Prediction (NWP) centers and end-users [29]. Real-time GODAE products span the range of observed and model-based fields of temperature, salinity, sea level, and flow field [30]. New initiatives such as the integrated MERSEA (Marine Environment and Security for the European Area) system provide a European capacity for ocean monitoring and forecasting in areas such as the Mediterranean Sea, the Baltic Sea, North Sea, and North Atlantic. What were once traditional NWP centers are now beginning to provide marine environmental forecast products such as the UK Met Office's AlgaRisk products for model-based chlorophyll, diatoms, dinoflagellates, and upper ocean stratification.

Forecasting of marine variability often emphasizes the shorter time scales and the coastal domain. Recent research on these space-time scales has illustrated the importance of air-sea coupling for tropical cyclogenesis. Fields of tropical cyclone heat potential derived from Jason-1, GFO (GEOSAT (Geodetic Satellite) FollowOn) and ENVISAT (Environmental Satellite) altimeter observations during the progression of hurricane Katrina have demonstrated the importance of ocean heat content to the explosive growth of major hurricanes [31]. Such studies have also served to bridge what here-to-fore have been both an observational and a research gap between the open ocean and the coastal ocean. Proposed new satellite missions such as the Surface Water Ocean Topography Mission have been designed from the outset to bridge these domains [32].

Beyond ocean weather and provision of marine services, in certain areas there is a wealth of observational evidence to draw on linking physical oceanography with ecosystem variability in the coastal zone. One of the best examples of which is the 60 years of observations within the California Coastal Current system provided by CalCOFI (California Cooperative Oceanic Fisheries Investigations). Such observations have permitted the 
discrimination of the separate influences of ENSO (El Niño/Southern Oscillation) and PDO (Pacific Decadal Oscillation) temporal variability upon two dominant euphuasids in the region, thus providing the basis for future forecasting of marine ecosystem variability in the region [33 and 34]. In addition to the space-based remote sensing mentioned above, this is also a region where new in situ technology such as gliders is showing considerable promise for autonomous monitoring of coastal and boundary currents [35].

\section{SUSTAINABLE MANAGEMENT}

With respect to sustainable management, as it pertains to the upper trophic levels, there is a pressing need to establish baselines upon which to evaluate specific management practices. Fundamental to principles of sustainable management is the ability to discriminate between natural variability of a particular marine resource versus changes due to man. The Tagging of Pacific Predators (TOPP) field program of the Census of Marine life has served to establish such a baseline for marine vertebrates. The TOPP program has tracked 19 species of marine vertebrates within the Pacific Ocean and examined the data with respect to the underlying oceanographic features that may be responsible for the observed patterns [36]. The challenges and multiple stressors to be confronted by sustainable management are illustrated in the case for South Africa by [37]. Be it changes in the frequency of Benguela Niños, changes in upwelling in southern Benguela in response to climate change, impact of ocean dynamics on fisheries in the Agulhas Bank, wave-current interaction and extreme wave events on coastal shipping, or the impact of rising sea level on coastal communities are just some of the myriad different influences that can impact sustainable management practices. In Europe, water quality products and algal bloom forecasts are produced as part of the GMES MarCoast (Global Monitoring for Environment and Security, Marine \& Coastal Environmental Information Services) initiative, and in North America NOAA (National Oceanic and Atmospheric Administration) routinely issues harmful algal bloom bulletins for regions such as the Gulf of Mexico [38].

It is worth pointing out that sustainable management in the Gulf of Mexico transcends just a focus on the coastal oceanography of the region or mere links between the coastal ocean and the open ocean. Rather, the Gulf of Mexico is a microcosm of the Earth system as a whole. As such, an integrated ecosystem assessment for the Gulf of Mexico in support of sustainable management must take into account a range of influences in the region such as the Loop Current, the role of extreme events such as hurricanes, coastal communities, heavy industry, sustainable fisheries, continued loss of coastal wetlands, and the influence of the entire Mississippi River basin on nutrient input to the Gulf's hypoxia [39].

At the Earth System Science Interdisciplinary Center, University of Maryland, a Chesapeake Bay Forecast System (CBFS) has been developed as a prototype regional Earth System model for decision support of sustainable management. The objective of this activity has been to develop a fully integrated model of the Chesapeake Bay and its air and watershed. The purpose being to provide near real-time applications, i.e., nowcasting and forecasting of the Bay circulation, ecosystem, pathogens, harmful algal blooms, waves and inundation, and on longer time scales utilize climate projections to estimate the effect of climate change between now and 2050 on the health of the Bay and its watershed. Key components of CBFS are oceanatmosphere-land-ecosystem models constrained by observations across all factors influencing the bay. The design and provision of a decision support tool allows end-users to set the region and time scale of interest, to perform "if-then" scenarios based on changes to input variables such as population density, $\mathrm{CO}_{2}$ concentration, land use, stream runoff, and/or agricultural practices with output chosen as a function of variables such as sea level, storm surge, inundation, air quality, precipitation, fish, crabs, sea nettles, algal bloom, phosphorus, oxygen, nitrogen, temperature, and/or salinity [40, 41 and 42]. Key to the success and evolution of any such system is the need to work with the end users right from the outset. Pilot applications and evaluation activities of the CBFS include forecasting future drinking water in an urbanizing warmer world, habitat suitability forecasting for Chesapeake Bay's striped bass population, evaluation of harmful algae forecasts for Chesapeake Bay, and working with watershed groups to evaluate how they can best benefit from the output and improve such environmental products. An ultimate goal of the CBFS is to provide a reliable end to end early warning system for the Chesapeake Bay and input to sustainable management decisions.

\section{LONGER-TERM TRENDS}

Much like the Keeling curve for atmospheric $\mathrm{CO}_{2}$ concentration, owing to sustained observations over the past decade and longer, a number of times series of oceanographic parameters are emerging upon which to assess long-term trends. Primary among these is that of global sea level rise. At the time of OceanObs'99 there were nearly seven years of TOPEX/Poseidon altimeter observations available. That time series has since been extended another 10 years and serves as one of the most iconic depictions of long-term oceanographic trends indicating a mean sea level rise at $3.1 \mathrm{~mm} / \mathrm{y}$ [22]. Such changes are also reflected within in situ based measures of ocean heat content going back over more than 50 years 
[43, 39]. At high latitudes where climate change has been predicted to be most severe, satellite observations of sea ice concentration and extent have placed the dramatic decrease of 2007 Arctic sea ice extent into a larger context of secular decrease over the past 30 years [44]. With respect to future sea level rise, one of the largest uncertainties is our knowledge of ice sheet dynamics. A good example of which was the 2002 breakup of the Larsen Ice Shelf in Antarctica and our lack of appreciation at the time for the importance of melt ponding in accelerating the break up [45]. Another concern for the future is the state of the Atlantic MOC (Meridional Overturning Circulation). Of the coupled climate models consistent with late $20^{\text {th }}$ century observational estimates, none show an increase in the AMOC (Atlantic Meridional Overturning Circulation) projecting to 2100; rather reductions range from indistinguishable within the range of simulated natural variability to deceases more than $50 \%$ relative to the 1960 to 1990 mean [46]. As a result there are now a number of observational programs measuring components of the AMOC. A question for the future is the extent to which there is a possibility to detect early warning signs of potential abrupt climate change related to the AMOC. One of the more problematic and disturbing long-term trends is the increase in seawater $\mathrm{pH}$ observed at Ocean Station Aloha over the past 17 years [47]. This increasing acidification reflects the increase in local $\mathrm{pCO}_{2}$ and is consistent with the increase in atmospheric $\mathrm{CO}_{2}$ observed at Mauna Loa (the aforementioned Keeling curve). Given the deleterious implications for marine ecosystems, potential ocean acidification monitoring sites have been proposed for both the open ocean and coastal regions.

\section{SUMMARY}

With the benefit of 20-20 hindsight much of the vision of OceanObs'99 has been realized with respect to physical oceanographic observations to support climate research. This represents a significant achievement by the oceanographic community. Over these years, real-time global ocean data have been obtained. This represents a true cultural shift in oceanography where now oceanographic data are routinely, freely and readily available. Access to such data has enabled initial steps toward marine core service activities. During this time there has also been a preliminary broadening in the scope of the observing system up from the backbone provided by the physical oceanographic parameters to include initial measures of carbon and chemistry. Yet, deficiencies remain, for example, in our coverage and understanding of certain processes at high latitudes, western boundary currents, and the deep ocean. Moreover, there is a long way to go before comprehensive forecasting of marine variability is realized or sustainable management implemented in the larger sense. The latter will require integration of physical, chemical, and biological observations within a modeling construct that integrates across these disciplines from global to regional scales.

The challenges for the future are many, but the progress of the past decade would suggest they are not insurmountable. Chief among these is the need to sustain today's global observations. Related to this challenge is the importance of initiating a global framework for marine core services. In one sense this can be viewed as the ocean component of climate services. The provision of marine core services and justification of global ocean observations are inextricably linked; for it is the routine provision of marine core services that will generate the operational demand for the global ocean observations. Another related challenge is the importance of linking and bridging blue and brown water, i.e. the global and coastal ocean. A good example of which is the sea level rise problem. At present, we do not have a good understanding of what controls the distribution of future sea level rise on regional scales. Yet, much like the case of global mean temperature being a convenient metric of climate change, what is most important to society is how temperature, precipitation, and sea level will change on regional scales. Looking to the future there is a clear need to expand the observational suite up from and beyond physical oceanography to encompass many aspects of biogeochemistry. This is most strikingly illustrated by changes to the ocean carbon cycle and the impact of acidification on marine life. There is also a need for increased emphasis on the utilization of ocean observations in climate prediction. Since the successful prediction of the 1997-1998 El Niño, the information content contained within the past decade's new in situ and remotely-sensed ocean observations has not been exploited to the fullest extent possible. This will prove ever more important for decadal climate prediction where there is a need to determine the optimal time-space sampling of the ocean needed to advance prediction on these timescales. Lastly, there is a need for greater engagement with the end users of ocean information. In order for the entire oceanographic enterprise to be sustained across basic research, applied research, longterm ocean monitoring, prediction and provision of marine core services, the needs of the end users must be an integral part of every step in this process. If, as an oceanographic community, we are successful in this regard, by 2019 we will be able to look back and note that the advances between OceanObs'99 and OceanObs'09 pale in comparison to those that transpired in the decade that followed.

\section{REFERENCES}

1. McPhaden, M. \& Co-Authors (2010). "The Global Tropical Moored Buoy Array" in these proceedings (Vol. 2), doi:10.5270/OceanObs09.cwp.61. 
2. Xue, Y. \& Co-Authors (2010). "Ocean State Estimation for Global Ocean Monitoring: ENSO and Beyond ENSO" in these proceedings (Vol. 2), doi:10.5270/OceanObs09.cwp.95.

3. Freeland, H. \& Co-Authors (2010)."Argo - A Decade of Progress" in these proceedings (Vol. 2), doi:10.5270/OceanObs09.cwp.32.

4. Goni, G. \& Co-Authors (2010). "The Ship of Opportunity Program" in these proceedings (Vol. 2), doi:10.5270/OceanObs09.cwp.35.

5. Merrifield, M. \& Co-Authors (2010). "The Global Sea Level Observing System (GLOSS)" in these proceedings (Vol. 2), doi:10.5270/OceanObs09.cwp.63.

6. Send, U. \& Co-Authors (2010). "A Global Boundary Current Circulation Observing Network" in these proceedings (Vol. 2), doi:10.5270/OceanObs09.cwp.78.

7. Worley, S. \& Co-Authors (2010). "The Role of the International Comprehensive Ocean-Atmosphere Data Set in the Sustained Ocean Observing System" in these proceedings (Vol. 2), doi:10.5270/OceanObs09.cwp.94.

8. Snowden, D. \& Co-Authors (2010). "Metadata Management in Global Distributed Ocean Observation Networks" in these proceedings (Vol. 2), doi:10.5270/OceanObs09.cwp.84.

9. Yu, L. \& Weller, R.A. (2007). Objectively Analyzed Air-Sea Heat Fluxes for the Global Ice-Free Oceans (1981-2005). Bull. Amer. Meteor. Soc. 88, 527-539

10. Cronin, M. \& Co-Authors (2010). "Monitoring Ocean Atmosphere Interactions in Western Boundary Current Extensions" in these proceedings (Vol. 2), doi:10.5270/OceanObs09.cwp.20.

11. Monteiro, P. \& Co-Authors (2010). "A Global Sea Surface Carbon Observing System: Assessment of Changing Sea Surface $\mathrm{CO} 2$ and Air-Sea CO2 Fluxes" in these proceedings (Vol. 2), doi:10.5270/OceanObs09.cwp.64.

12. Takahashi, T. \& Co-Authors. (2009). Climatological Mean and Decadal Change in Surface Ocean pCO2, and Net Sea-Air CO2 Flux Over the Global Oceans. Deep-Sea Res. II, 56, 554-577, doi:10.1016/j.dsr2.2008.12.009.

13. Rienecker, M. \& Co-Authors (2010). "Synthesis and Assimilation Systems - Essential Adjuncts to the Global Ocean Observing System" in these proceedings (Vol. 1), doi:10.5270/OceanObs09.pp.31.

14. Stammer, D. \& Co-Authors (2010). "Ocean Information Provided Through Ensemble Ocean Syntheses" in these proceedings (Vol. 2), doi:10.5270/OceanObs09.cwp.85.

15. Gruber, N. \& Co-Authors (2010). "Adding Oxygen to Argo: Developing a Global In Situ Observatory for Ocean Deoxygenation and Biogeochemistry" in these proceedings (Vol. 2), doi:10.5270/OceanObs09.cwp.39.
16. Claustre, H. \& Co-Authors (2010). "Bio-Optical Profiling Floats as New Observational Tools for Biogeochemical and Ecosystem Studies: Potential Synergies with Ocean Color Remote Sensing." in these proceedings (Vol. 2), doi:10.5270/OceanObs09.cwp.17.

17. Charrassin, J. \& Co-Authors (2010). "New Insights into Southern Ocean Physical and Biological Processes Revealed by Instrumented Elephant Seals" in these proceedings (Vol. 2), doi:10.5270/OceanObs09.cwp.15

18. Shum, C. \& Co-Authors (2010). "Geodetic Observations of the Ocean Surface Topography, Geoid, Currents, and Changes in Ocean Mass and Volume" in these proceedings (Vol. 2), doi:10.5270/OceanObs09.cwp.80.

19. Maximenko, N., Niiler, P. Rio, M.H. Melnichenko, O. Centurioni, L. Chambers, D. Zlotnicki, V. \& Galperin, B (2009). Mean dynamic topography of the ocean derived from satellite and drifting buoy data using three different techniques. J. Atmos. Oceanic Tech., 26(9), 1910-1919.

20. Lagerloef, G. \& Co-Authors (2010). "Resolving the Global Surface Salinity Field and Variations by Blending Satellite and In Situ Observations" in these proceedings (Vol. 2), doi:10.5270/OceanObs09.cwp.51.

21. Stockdale, T. \& Co-Authors (2009). "Understanding and Predicting Seasonal to Interannual Climate Variability the producer perspective", World Climate Conference -3 White Paper, http://www.wcc3.org/wcc3docs/pdf/WS3_WP_capability .pdf, Geneva Switzerland, 31 August 4 September 2009.

22. Nerem, R. \& Co-Authors (2010). "Observations of Sea Level Change: What Have We Learned and What Are the Remaining Challenges?" in these proceedings (Vol. 2), doi:10.5270/OceanObs09.cwp.65.

23. Scott, R. \& Co-Authors (2010). "Satellite Altimetry and Key Observations: What We've Learned, and What's Possible with New Technologies" in these proceedings (Vol. 2), doi:10.5270/OceanObs09.cwp.76.

24. Smith, D. M. \& co-authors, 2007: Improved surface temperature prediction for the coming decade from a global climate model. Science, 317, 796-799.

25. Keenlyside, N., M. Latif, J. Junclaus, L. Kornblueh and E. Roeckner, 2008: Advancing decadal climate scale prediction in the North Atlantic. Nature, 453, 84-88.

26. Pohlmann H, J. H. Jungclaus, A. Köhl, D. Stammer and J. Marotzke, 2009: Initializing Decadal Climate Predictions with the GECCO Oceanic Synthesis: Effects on the North Atlantic. J. Climate, in press.

27. Hurrell, J. \& Co-Authors (2010). "Decadal Climate Prediction: Opportunities and Challenges" in these proceedings (Vol. 2), doi:10.5270/OceanObs09.cwp.45

28. Malone, T. \& Co-Authors (2010). "Building a Global System of Systems for the Coastal Ocean: A Strategic 
Action Plan for Implementing the Coastal Module of GOOS" in these proceedings (Vol. 2),

doi:10.5270/OceanObs09.cwp.59.

29. Le Traon, P., Bell, M., Dombrowsky, E., Schiller, A. and Wilmer Becker, K., (2010)."GODAE OceanView: from an Experiment Towards a Long-Term International Ocean Analysis and Forecasting Program" in these proceedings (Vol. 2), doi:10.5270/OceanObs09.cwp.57.

30. Blanc, F. \& Co-Authors (2010). "Evolution in Data and Product Management for Serving Operational Oceanography, a GODAE Feedback" in these proceedings (Vol. 2), doi:10.5270/OceanObs09.cwp.05.

31. Goni, G. \& Co-Authors (2010). "The Ocean Observing System for Tropical Cyclone Intensification Forecasts and Studies" in these proceedings (Vol. 2), doi:10.5270/OceanObs09.cwp.36.

32. Fu, L. \& Co-Authors (2010). "The Surface Water and Ocean Topography (SWOT) Mission" in these proceedings (Vol. 2), doi:10.5270/OceanObs09.cwp.33.

33. Brinton, E., and A. Townsend (2003) Decadal variability in abundances of the dominant euphausiid species in southern sectors of the California Current. Deep-Sea Res II 50, 2449-2472.

34. Koslow, J., Goericke, R., McClatchie, S., Vetter, R. and Rogers-Bennett, L., (2010). "The California Cooperative Oceanic Fisheries Investigations (CalCOFI): The Continuing Evolution and Contributions of a 60-Year Ocean Observation Program" in these proceedings (Vol. 2), doi:10.5270/OceanObs09.cwp.49.

35. Testor, P. \& Co-Authors (2010). "Gliders as a Component of Future Observing Systems" in these proceedings (Vol. 2), doi:10.5270/OceanObs09.cwp.89.

36. Costa, D., Block, B., Bograd, S., Fedak, M. and Gunn, J., (2010). "TOPP as a Marine Life Observatory: Using Electronic Tags to Monitor the Movements, Behaviour and Habitats of Marine Vertebrates" in these proceedings (Vol. 2), doi:10.5270/OceanObs09.cwp.19.

37. Cipollini, P. \& Co-Authors (2010). "The Role of Altimetry in Coastal Observing Systems" in these proceedings (Vol. 2), doi:10.5270/OceanObs09.cwp.16.

38. Beegle-Krause, C. \& Co-Authors (2010). "Observations as Assets in Decision Support" in these proceedings (Vol. 2), doi:10.5270/OceanObs09.cwp.03.

39. Conkright Gregg, M., Newlin, M., LeDuc, S., Keeley, R. and D'Adamo, N., (2010)."Ocean and Coastal Data Stewardship" in these proceedings (Vol. 2), doi:10.5270/OceanObs09.cwp.18.

40. Murtugudde, R., 2009: Regional Earth System prediction: A decision-making tool for sustainability? Curr. Op. Environ. Sust., 1, 37-45.
41. Murtugudde, R. (2010). "Observational Needs for Regional Earth System Prediction" in these proceedings (Annex).

42. Nobre, C. A., G. P. Brasseur, M. A. Shapiro, M. Lahsen, G. Brunet, A. J. Busalacchi, K. Hibbard, S. Seitzinger and K. Noone (2010). "Addressing the complexity of the Earth System". Bull. Amer. Met. Soc., 91, 1389-1396. doi: 10.1175/2010BAMS3012.1.

43. Levitus, S., J. I. Antonov, T. P. Boyer, R. A. Locarnini, H. E. Garcia and A. V. Mishonov (2009), Global ocean heat content 1955-2008 in light of recently revealed instrumentation problems, Geophys. Res. Lett., 36, L07608, doi:10.1029/2008GL037155.

44. Breivik, L. \& Co-Authors (2010). "Remote Sensing of Sea Ice" in these proceedings (Vol. 2), doi:10.5270/OceanObs09.cwp.11.

45. Rintoul, S. \& Co-Authors (2010). "Southern Ocean Observing System (SOOS): Rationale and Strategy for Sustained Observations of the Southern Ocean" in these proceedings (Vol. 2), doi:10.5270/OceanObs09.cwp.74.

46. Cunningham, S. \& Co-Authors (2010). "The Present and Future System for Measuring the Atlantic Meridional Overturning Circulation and Heat Transport" in these proceedings (Vol. 2), doi:10.5270/OceanObs09.cwp.21.

47 Feely, R. \& Co-Authors (2010). "An International Observational Network for Ocean Acidification" in these proceedings (Vol. 2), doi:10.5270/OceanObs09.cwp.29. 